\title{
HERINNERINGEN AAN HET OERWOUD
}

\author{
VISCHVANGST IN SURINAME
}

DOOR

\section{JUNKER}

Evenals de jacht vervult de vischvangst een voorname rol bij de voedselvoorziening in Suriname. Ofschoon het in mijn bedoeling ligt, in de eerste plaats deze voedselvoorziening bij de primitieve bewoners van het land te bespreken en daarbij rekening te houden met de bewoners der buitendistricten, zal een korte beschouwing van de visscherij in het algemeen en van de voorziening van visch der stadsbewoners wel op haar plaats zijn.

In het algemeen geeft de bevolking van Suriname voorkeur aan de uit de Vereenigde Staten ingevoerde gezouten visch, waarvan verschillende soorten onder den verzamelnaam bakkeljouw bekend zijn. Het verbruik hiervan is niet slechts een kwestie van smaak, doch heeft in de eerste plaats een economischen achtergrond. Voor een paar luttele centen kan de vrouw uit het volk bij den Chinees voor het middagmaal terecht en deze visch wordt genuttigd als toespijs bij het frugale ontbijt of bij het avondeten van den gewonen arbeider. De bakkeljouw wordt dan ook in groote hoeveelheden ingevoerd. Dit neemt niet weg, dat er door beroepsvisschers nog groote hoeveelheden versche, gedroogde en ook gezouten visch aan de markt gebracht wordt. Alleen gedroogde visch kan bewaard worden; anders bederft de visch, zelfs goed doorgebakken, spoedig. De visscherij wordt zoowel op de rivieren als ook in de moerassen uitgeoefend. Terwijl de beroepsvisschers op de rivieren gedurende het geheele jaar hun netten op de groote modderbanken uitzetten wordt in zwampen slechts gedurende den drogen tijd, wanneer deze nagenoeg uitdrogen, gevischt. In het jaar 1909 werd een onderneming opgericht, die zich ten doel stelde zeevisch te Paramaribo aan de markt te brengen. De kotter, die naar den Atlantischen Oceaan ter vischvangst toog, nam groote hoeveelheden ijs mede, waarin

$$
-143-
$$


de gevangen visch bewaard werd. Na terugkeer werd de vangst te Paramaribo in de koelkamers der ijsfabriek opgeslagen. De aldus bewaarde visch viel echter niet in den smaak van het publiek en in 1913 werd de onderneming gestaakt.

Met het oog op den grooten vischrijkdom der Surinaamsche rivieren en kreken, doch vooral van de zee langs de kust, werd het denkbeeld geopperd hiervan voor den economischen opbouw van Suriname partij te trekken. Men meende, dat de bereiding van vischmeel, dat als krachtvoeder voor vee in Nederland afzet zou kunnen vinden, op geen onoverkomelijke bezwaren zou stuiten. Zoowel de monding van de Surinamerivier met de verlaten suikerplantage Resolutie, als ook Nickerie, zijn zoowel voor de productie als voor de verscheping zeer gunstig gelegen. Met het produceeren van vischmeel kan het winnen van vischlijm gepaard gaan. Deze wordt vooral door de veel in de Surinaamsche wateren voorkomende visschen van de familie der Siluridae, waarvan de Geelbagger (Sciadeichtys Parkeri) de grootste vertegenwoordiger is, geleverd. Deze visch wordt tot anderhalve meter lang en meer dan honderd pond zwaar. Ofschoon zijn vleesch zeer smakelijk is, en de visch zoo goed als geen graten bezit, wordt hij, behalve door de Indianen en Boschnegers, door de inwoners niet gegeten, evenmin als de overige gladvisschen, zooals men in Suriname de Siluridae noemt. Het volksgeloof wil, dat deze visch treef voor den mensch is, d.w.z., dat het eten van die visschen melaatschheid veroorzaakt.

Zooals de jacht is ook het visschen in Suriname aan geen wetten gebonden. Slechts de beroepsvisschers zijn gehouden een kostelooze vergunning aan te vragen. Buitendien bestaat er een verbodsbepaling tegen het vangen van visch door middel van vischvergiften. Deze bepaling wordt echter in het binnenland niet nageleefd. In zekere streken is het ponsen, de uitdrukking voor visschen met vischvergiften, zelfs noodzakelijk. De hoofdbron van inkomsten der bewoners van het Surinaamsche binnenland is de houtkap. Het gekapte hout wordt naar de kreken gesleept en aldaar tot vlotten vereenigd. In deze waterwegen wemelt het dikwijls van gevaarlijke visschen. Vooral de sipari (potamotrygon reticulatus) wordt vaak in de kreken aangetroffen. Aan het einde van zijn zweepachtigen staart draagt deze visch een tot tien centimeter langen doorn, waarmee hij den mensch verwondingen toebrengt, welke tot gevaarlijke ontstekingen kunnen leiden, die zeer moeielijk te genezen zijn. Evenals tegen slangenbeten bezitten de inboorlingen wel een voorbehoedmiddel, een kotti, dat is 
een inenting, doch te oordeelen naar de vele wonden, welke ik gedurende mijn zwerftochten behandeld heb, helpt het middel niet veel. Het beste voorbehoedmiddel blijft daarom het bij voorbaat onschadelijk maken van den aanvaller door een kreek, waarin gewerkt moet worden, te ponsen. Van dezen gevaarlijken visch dient vermeld te worden, dat hij tot één der Surinaamsche rivieren, den Granrio, geen toegang heeft weten te verkrijgen. Deze rivier, welke samen met den Pikienrio de Surinamerivier vormt, wordt bij de samenvloeiing door een tien meter hoogen rotsdam, welke gedurende den regentijd in een indrukwekkende waterval verandert, afgesloten. Den sipari is het nooit gelukt over den dam heen naar den Granrio te komen. Daarentegen is een andere gevaarlijke visch, de piring, de gevaarlijkste roofvisch van alle Zuidamerikaansche rivieren, daar wel te vinden. Op dezen roover zullen wij later herhaaldelijk terug komen.

Alvorens wij nader de methoden van de vischvangst der primitieve en half primitieve bewoners van Suriname bespreken, zullen wij ons wat bij de beroepsvisschers ophouden. Deze zoeken hun arbeidsveld in zee langs de kust, in de groote rivieren of in de moeraskreken. In de beide eerste gevallen wordt steeds op een modderbank gevischt. Heeft men een geschikte bank aangetroffen, dan worden naar gelang van de lengte van het net - deze kan 150-200 m zijn - in een grooten boog, die van oever tot oever loopt, lange stokken in de modder gedreven. Aan deze stokken wordt het net bevestigd en opgerold. Komt nu de vloed op, dan stroomt het water onder het opgerolde net door en daarmede komen ook de visschen binnen, die op de modderbanken naar hun voedsel zoeken. Wanneer het water hoog genoeg is en over het opgerolde net heen stroomt, wordt dit los gemaakt. De onderkant daarvan is voorzien van looden kogels, welke in de modder dringen en zóó het net spannen. Hierdoor wordt den visschen, die met de eb weder naar de zee willen terugkeeren, de terugtocht afgesneden en blijven deze op de modderbank liggen. De buit is soms zeer groot en van groote verscheidenheid. In het bijzonder wordt vaak aldus de gweriman, (Mugil brasiliensis) in groote hoeveelheden gevangen. Deze, een van de smakelijkste zeevisschen, die veel overeenkomst met den zalm heeft, wordt tot een halve meter lang en wel tien ponden zwaar. Hij komt in groote scholen op de modderbanken voor, waarop hij door opslurpen van de modder op kreeften en weekdieren jacht maakt. Ofschoon de gweriman in grooten getale over het net heen springt, worden altijd nog veel laatkomers gevangen. Maar ook

West-Indische Gids XXIV 
kleine haaien en vooral de zaagvisch behooren tot de regelmatige bezoekers der Surinaamsche kust. Het water is tot nagenoeg drie mijlen van de kust troebel en modderig. De groote menschenhaai komt niet naar dit water; hij houdt zich in het diepe en heldere zeewater op. Rondom de voor de kust van Fransch Guyana gelegen Iles du Salut, welke als verbanningsoorden voor Fransche misdadigers berucht zijn, komt de menschenhaai in grooten getale voor. Hij speelt aldaar de rol van wachter, en loert tevens op de lijken van de verbannenen, die volgens Kappler op de eilanden niet begraven maar in zee geworpen worden. Ook de zaagvisch (Pristis antiquorum Lath.) kan niet als een gewenschte gast op de Surinaamsche kust beschouwd worden. Dit blijkt hieruit, dat, toen ruim twintig jaren geleden eenig personeel van de zendingsfirma een uitstapje naar het strand nabij de uitmonding van de Surinamerivier maakte, gedurende het baden bij opkomenden vloed een van hen door een zaagvisch werd aangevallen en hem een been letterlijk werd afgesneden. De ongelukkige, een van de chefs der firma, was niet meer te redden en bloedde dood. In de netten der visschers worden zaagvisschen van zes meters lengte gevangen; in den regel bedraagt de lengte van de zaag ongeveer een derde der geheele lengte van den visch. Meestal zijn de zaagvisschen van kleinere afmetingen en hun zagen worden als Surinaamsche curiositeiten te Paramaribo te koop aangeboden.

Op hooge plekken van het strand richten de visschers de barbacot op. Deze bestaat uit een stellage van stevige stokken, waarop bij wijze van een rooster eveneens stokken worden gelegd. Onder het rooster wordt een open vuur onderhouden; de visschen worden dus niet gerookt maar geroosterd. Wanneer de visschen zoo droog als beschuit zijn, worden zij verpakt en te $\mathrm{Pa}-$ ramaribo verhandeld. Dikwijls wordt een gedeelte van de gevangen visch slechts half gedroogd, en dit product als ,,warme visch", waram fisi in het negerengelsch, te koop aangeboden. Deze visch blijft dan echter ten hoogste een of twee dagen goed, terwijl de geroosterde visch gedurende weken bewaard kan worden.

De beroepsvisschers, die op de Surinaamsche rivieren visschen, doen dit met de zoogenaamde sleep. Dit is een net, dat aan den bovenkant van een groot aantal stukken licht hout, die het net drijvende houden, voorzien is. In het midden van den onderkant loopt het net in een lange zak uit. Met hoog water wordt het net op een modderbank in een grooten boog uitgezet, waarbij beide 
uiteinden aan den wal vastgemaakt worden. Zoodra verondersteld wordt, dat achter het net voldoende visch aanwezig is, wordt dit naar de wal toe getrokken, de vluchtende visch komt dan in den zak van het net terecht en kan zoodoende gemakkelijk bemachtigd worden. De visschers brengen hun buit zoo spoedig mogelijk naar Paramaribo, waar deze versch te koop aangeboden wordt.

Onder de visschen, die in de rivieren gevangen worden, neemt de Koebi (cynoscion acoupa) een voorname plaats in. In het bijzonder tegen het begin van den drogen tijd verlaat deze visch de zee, waarin hij thuis behoort, en komt in groote scholen de rivieren binnenvallen. Gedurende Juli en Augustus heb ik de koebi dikwijls ter hoogte van de Jodensavanna gevangen. Dit is een van de smakelijkste visschen, wordt meer dan een halve meter lang en kan wel acht pond zwaar worden. Verder is er nog de snoek, die wel twintig pond zwaar kan worden, en de boven reeds genoemde gweriman.

Eenige schollensoorten en een haringachtige visch, dien men in Suriname sardine noemt, behooren eveneens tot de betere vischsoorten. Soms maakt ook de Granmorgo, de grootste schubbenvisch, die de Surinaamsche wateren bezoekt, het den visschers lastig. Deze, de Hypoplectrus, kan tot twee meters lang en een meter hoog worden. Er werden visschen van deze soort gevangen, die nagenoeg 300 pond zwaar waren. Behalve nog meer kleinere schubbenvisschen, waarvan de namen mij onbekend zijn, worden in de rivieren nog een aantal soorten visschen gevangen, welke tot de familie der Siluridae behooren.

De visscherij der beroepsvisschers in de bosch- en moeraskreken beperkt zich tot den drogen tijd, wanneer de waterstand laag is en de werking der getijden een handje mee helpt. Bij hoog water worden de mondingen der kreken met het net afgesloten en de naar de grootere kreken of rivieren terugkeerende visch wordt in den zak van het net gevangen. Ofschoon talrijke soorten gevangen worden, komen voor deze vangst slechts de Warappa (Hoplerythricus) en de Batakka (Macrodon trahira Spix) in aanmerking. Gene is een overal in de moerasstreken voorkomende visch, welke ongeveer $30 \mathrm{~cm}$ lang wordt, weinig graten heeft, zeer vet wordt en de smakelijkste moerasvisch is. Terwijl men de warappa ook levend naar Paramaribo vervoert, wordt het meerendeel van de gevangen visch ter plaatse gezouten en in vaten verpakt. De batakka wordt op de barbacot geroosterd en als drefisi, gedroogde vsich, aan de markt gebracht. Deze visch wordt veel grooter dan de warappa en heeft veel graten, maar 
wordt voor de bereiding van de blafoe, de Surinaamsche soep. zeer gezocht. In dit verband kunnen wij ook den kwikwi (Callichthys) noemen. Van deze visch, waarvan het geheele lichaam met hoornen platen bedekt is, en waarvan de vinnen hoornen doornen zijn, leven in de moerassen verscheidene soorten. Hij wordt ten hoogste $15 \mathrm{~cm}$ lang en kan uren buiten het water in leven blijven. Wanneer ondiepe moerassen uitdrogen, kruipt de kwikwi over diepe plekken der zwamp, of boort zich in den vochtigen grond en houdt aldaar een aardewinterslaap. Door de bewoners van Paramaribo is het hengelen van kwikwi gedurende den drogen tijd een geliefde sport.

$\mathrm{Na}$ deze beschrijving van een gedeelte van de voedselvoorziening der stadsbewoners, komen wij op ons eigenlijk onderwerp, de wijze, waarop de primitieve en andere bewoners van het binnenland door visschen in hun voeding voorzien, te spreken. $\mathrm{Zij}$ bezitten geen netten; in plaats daarvan treffen wij echter bij hen de Indiaansche para aan. Uit de bladsteelen der Maripapalm snijdt men dunne, maar dan twee meters lange, latjes. Deze worden door middel van een bosch touw, verkregen van een liaan, aan elkander geregen, zoodat hierdoor een opengewerkte 8 à 10 meters lange en ongeveer twee en een halve meter hooge mat ontstaat. Zoowel de mondingen van kleine kreken, alsook zand- en modderbanken in de rivieren, worden door deze para, waarvan er soms twee à drie noodig zijn, afgezet. Wanneer de banken of de mondingen der kreken droog liggen, worden lange stokken in den grond gedreven, waaraan de para bevestigd wordt. Daar, waar de trek van het water het grootst is, laat men een eenige meters breede opening in het scherm. Met den opkomenden vloed trekken de visschen daar door heen, en zoodra het water zijn hoogsten stand bereikt heeft, wordt het gat in de para gesloten. Men wacht dan, totdat het water weer laag is, om de visschen van den drogen grond op te rapen. Omdat de kreken over dag door geheel andere visschen bezocht worden dan des nachts, worden, naarmate men des nachts of over dag vischt, geheel andere visschen gevangen. Op deze wijze worden des nachts op de zandbanken der rivieren soms vele honderden visschen in één vangst bemachtigd. In het bijzonder bezoekt de Makkavisch gedurende den nacht de zandbanken, en deze trekt op het einde van den regentijd in groote scholen naar de bovenrivieren. Deze, de Curimatus spilurus Gunth. wordt hoogstens een half pond zwaar, doch de moeite wordt beloond, doordat soms vele honderden achter de para blijven liggen. 
Ook op een andere wijze wordt visch in groote hoeveelheden gevangen, met de Massoea n.l. Dit instrument is een walsvormige, uit palmbladen gevlochten korf, waarvan beide uiteinden zóó worden afgesloten, dat de visch door de buigzame afsluiting wel in den korf kan komen, maar dezen niet meer verlaten kan. De Massoe wordt voornamelijk in kreken geplaatst en een of twee malen per week leeg gehaald. Ook bewaren de Indianen, wanneer zij bij de vangst bijzonder gelukkig zijn geweest, het surplus daarvan in soms eenige meters lange Massoeas.

Gedurende den regentijd loopen groote oppervlakten bosch onder en vullen zich talrijke beken, die later weer droog loopen. De visschen, in het bijzonder de warappa en de batakka, komen dan in groote scholen deze overstroomde streken binnentrekken. Voordat deze weder naar het diepe water terugkeeren, zetten de inboorlingen de beken met gevlochten palmbladeren af en plaatsen achter de hindernis een groote boot (corjaal). De terugkeerende visschen vinden de hindernis in hun weg en springen er overheen, waardoor zij in den corjaal terechtkomen en aldaar blijven liggen.

Een zeer vernuftig uitgedacht toestel van den primitieven visscher is de kamina, een op het grondbeginsel van den terugveerenden gebogen stok berustende springfuik. Deze stok wordt in de nauwe opening van een van palmhoutlatten en lianen gevlochten suikerbroodvormigen korf bevestigd. De open onderkant daarvan wordt door een eveneens stevig gevlochten deksel afgesloten, dat met het uiteinde van den stok door een boschtouw verbonden is. Aan dit touw wordt de val bevestigd, waaraan, zooals bij een eenvoudige muizenval, het lokaas vastgemaakt wordt. Wanneer dit geschied is, wordt de stok gebogen, waardoor het touw slap en het deksel geopend wordt. Rukt de visch aan het lokaas, dan springt de kuip van de val uit haar rustpunt, waardoor het touw vrij komt en de stok terugveert. Het touw wordt gespannen en sluit het deksel, de visch kan vóór noch achteruit, hij zit gevangen.

Met behulp van deze springfuiken vangen de Indianen in de boschkreken soms honderden visschen per dag, meestal warappen en batakken. Eens marcheerde ik met mijn arbeiders aan de Boven-Saramacca en kruisten wij den bovenloop van een der kreken dezer rivier. Juist bij den overgang der kreek was een springfuik aan een klein boompje bevestigd en in de fuik zat een visch. Wij zetten onze vrachten neer en gingen op nader onderzoek uit. Toen er nog een twintig fuiken met inhoud gevonden 
waren, werd besloten ter plaatse te rusten en van den gevangen visch het middagmaal te bereiden. Een van de arbeiders zette de vallen weer, met versch lokaas op, zoodat de Indiaan, die deze geplaatst had, geen schade heeft ondervonden.

Een bijzonder stevige en groote kamina wordt voor de Anjoemara gevlochten. Deze, de Macrodon aimara Spix. is een van de beste zoetwatervisschen van Suriname. Hij wordt tot een meter lang en kan vijf en twintig pond zwaar worden. Naast de piring is de anjoemara de gevaarlijkste roover onder de visschen der rivieren en kreken van het binnenland. De beet van dezen visch is daarom bijzonder gevaarlijk, omdat de veroorzaakte wonden zeer slecht genezen en allerlei complicaties met zich brengen. Dit heb ik eens, op een reis naar de Tapanahony, aan de Tossokreek ondervonden. Een arbeider, die heel voorzichtig op een rots in de kreek een bad nam, werd aan zijn hiel door een anjoemara gebeten. Hoewel de wond antiseptisch behandeld werd, veretterde zij met den dag meer en ten slotte veroorzaakte dit klierontstekingen, zoodat ik den arbeider naar Paramaribo moest opzenden. Ook bij de Boschnegers kreeg ik herhaaldelijk door visschen veroorzaakte wonden, die niet genezen wilden, te behandelen.

Dikwijls, in het bijzonder wanneer het vleesch van het eene of andere wild als lokaas wordt gebruikt, komt ook de pirin (Pygocentrus piraya) in de fuiken terecht. Deze roover, die gemakkelijk door zijn roode oogen van de andere visschen te onderscheiden is, wordt wanneer er bloed in het water te ruiken is zeer brutaal, en komt dan, soms in heele scholen, tot dicht aan de landingsplaatsen, waar wild schoon gemaakt wordt. Menige Boschnegervrouw heeft haar onvoorzichtigheid met het verlies van een vinger moeten betalen. De pirin bijt met zijn vlijmscherp, zaagachtig gebit beenderen van vingerdikte met gemak af. Schildpadden en watervogels zijn dikwijls de slachtoffers van deze roofvisch. Bij Brokolanko, aan de Boven Saramacca, zag ik eens hoe een hond in eenige minuten door de pirins afgemaakt werd. Hij zwom zijn meester, die met de boot de rivier overgestoken was, achterna en werd in het midden van den stroom door een pirin aangevallen. Het uit de wonden van den hond vloeiende bloed lokte tal van pirins aan, die het arme, van pijn gillende dier letterlijk in stukken scheurden. Als men zwemmende in beweging blijft, valt de pirin niet aan; ik heb ten minste nooit gehoord, dat de visch in open en schoon water een mensch aangevallen heeft. 
Terwijl, behalve door de stadsbewoners, die gedurende den drogen tijd naar de moerassen trekken om kwikwi te vangen, weinig aan hengelen gedaan wordt, vangen de bewoners van het binnenland toch visschen met den haak. Meestal wordt van de zoogenaamde djompohoekoe, den springhengel, gebruik gemaakt. Deze berust op het beginsel van den terugspringenden gebogen staf. De haak wordt aan een buigzamen stok door middel van een gevlochten touw bevestigd en van lokaas voorzien. Daarna wordt de stok gebogen en, op de wijze welke wij bij de springfuik hebben leeren kennen, in zijn stand gehouden. Daarbij komt de haak met het aas in het water te liggen. Bijt de visch, dan rukt hij de houten kuip waarmede de stok in zijn gebogen stand vastgehouden wordt los, de stok komt vrij, springt terug en de visch komt boven den waterspiegel aan den zelfwerkenden hengel te hangen. Met dezen springhengel worden de grootste visschen zooals anjoemaras en gladvisschen gevangen. Zijn deze te groot, waardoor een gedeelte van het lichaam in het water blijft hangen, dan maakt de pirin van de gelegenheid gebruik om goedkoop aan een maal te komen. Dikwijls heb ik de Indianen met minder dan een halve visch terug zien keeren.

Een paar andere wijzen, waarop de inboorlingen trachten zich van visch te voorzien, zijn het tijdelijk gedurende de eb afdammen van kreken en het visschen des nachts met behulp van licht. De eerste wijze heeft alleen plaats in de streken, waar de getijden hun invloed uitoefenen. Hieronder valt het Savannagebied, dat voornamelijk door de benedenlandsche Indianen bewoond wordt. Een daartoe uitgekozen plek in de benedenloop van een kleine kreek wordt met hout en palmbladeren te voren zoodanig versperd, dat in het laatste stadium van de eb een aarden wal met gemak tegen de versperring gebouwd kan worden. Daarna begeven zich eenige inboorlingen naar den bovenloop der kreek en jagen de aldaar zich ophoudende visschen naar het diepere water, dat zich achter de versperring verzameld heeft. Is er nog tijd genoeg, voordat de opkomende vloed de versperring vernielt, of er over heen spoelt, dan wordt het water uit den plas gehoosd en de visschen met de hand gevangen. Komt het water echter aanstroomen, of is er te veel water achter den dam blijven staan, dan nemen de inboorlingen hun toevlucht tot het een of ander vischvergift.

Het vangen der visschen met licht heeft meestal op de groote rivieren plaats. De Indianen vervaardigen flambouwen van gedroogde bladstelen der maripapalm. Dikwijls wordt in de flam- 
bouwen ook het hars van den lokusboom of van een protiumsoort, de zoogenaamde tingimonni, verwerkt. In donkere nachten varen de Indianen in hun corjalen over de modder- en zandbanken, plekken, welke door de visschen, op jacht naar voedsel, gaarne bezocht worden, en het verblindende licht der flambouwen doet de visschen verschrikt een heenkomen zoeken. Daarbij springen zij tegen het licht in boven water en komen veelal in de boot terecht, waar zij of met de handen gegrepen, ò met het kapmes afgemaakt worden.

Een eigenaardige vischvangst, waarbij de maan voor belichting zorgde, beleefde ik eens diep in het oerwoud ten westen van den Granrio. Wij hadden kamp gemaakt aan een groote kreek, waarin even stroomopwaarts machtige rotsblokken een in den regentijd geduchten waterval vormden. Thans stroomde het water slechts zachtjes door twee geulen over het rotsgevaarte heen, juist diep genoeg om de anjoemara tot doorvaart te dienen. Sotia, een boschneger, die tusschen de rivier en de overige kampen als "maillooper" de verbinding onderhield, kwam op een avond met twee van die groote visschen van een uitstapje in den manenschijn terug. Hij vertelde, dat hij deze visschen op de Mooipan, zooals de soela of waterval genoemd werd, gekapt had. Wij spraken af, dat ik hem den volgenden avond zou vergezellen en dat wij dan samen anjoemaras zouden vangen. Zoo gebeurde het ook; wij trokken er in den avond op uit, en Sotia wees me de plaats bij een van de geulen, waarlangs de visch zijn weg naar de rivier moest nemen. Met beide voeten op een rotsplaat in het water staande, tuurde ik naar den zilveren flits, die in het donkere water moest oplichten om op hetzelfde oogenblik met het kapmes toe te slaan. De flitsen kwamen, ik sloeg toe, doch sloeg slechts schaarden in het vlijmscherpe kapmes. Sotia, die aan de andere geul stond was gelukkiger; tot tweemalen toe hoorde ik den plons van een door hem geraakten visch op de rots naast mij. $\mathrm{Na}$ bijna een uur tevergeefs op werkelijke en vermeende schitteringen in het water toegeslagen te hebben, gaf ik het op en begaf mij naar den fortuinlijken Boschneger. Hij had inderdaad wederom twee anjoemaras geraakt, waaronder een groote, die wel vijftien pond mocht wegen. Wij bleven nog wat vertoeven, eenige malen sloeg ook Sotia tevergeefs toe, en toen het scheen, dat er geen visschen meer zouden opdagen, keerden wij naar ons kamp terug.

Even goede oogen als voor deze wijze van vischvangst zijn ook voor het schieten van visch met pijl en boog noodig. Hierbij 
komt het er niet alleen op aan de visch in het water te ontdekken, doch het voornaamste is diens werkelijke plaats juist op te nemen. Dit is met het oog op het breken der lichtstralen moeielijker, naarmate de visch dieper in het water waargenomen wordt.

De Indianen bedienen zich voor de jacht op visschen van drie verschillende pijlen, welke slechts in de afwerking der pijlpunten van elkander verschillen. De pijlen zijn gemiddeld anderhalven meter lang en bestaan uit de van pijlriet gemaakte schacht en de daarop bevestigde punt. Deze laatste bestaat uit een eenvoudige ijzeren weerhaak, die nog door een kleineren haak ondersteund wordt, of de punt wordt uit drie weerhaken samengesteld. Deze twee soorten vischpijlen, waarvan de punten stevig met touw en hars aan de schacht verbonden zijn, worden voornamelijk op de oeverbanken en in het algemeen in ondiep water gebruikt. Gedurende den grooten regentijd loopen de oeverbanken en soms groote gedeelten laag land onder en gedurende denzelfden tijd rijpen ook tal van vruchten van boomen en heesters, die aan de rivierkanten groeien. Een groot aantal visschen, die tot de zalmachtigen behooren en zich uitsluitend met plantaardig voedsel voeden, bezoeken dan deze ondiepe plekken. Geruischloos, zonder het water in beweging te brengen, stuurt de Indiaan den corjaal tusschen de rechtopstaande stammen van de mokkomokko (Montrichardia), zachtjes wordt de paddel weggelegd, dan neemt hij pijl en boog ter hand en staat op. Met het ondereinde van den pijl op het koord staat hij bewegingsloos, slechts de oogen draaien in hun kassen. Daar wordt de rechterarm achteruit gebracht en bijna onmerkbaar de boog gespannen. Even daarna snort de pijl op zijn doel af en nagenoeg in hetzelfde oogenblik draait deze met schokken in het water rond. De Indiaan grijpt den pijl, trekt hem uit het water en daarmede den nog spartelenden visch. Waar gevaar bestaat, dat een geraakte visch onderduiken en met den pijl in diep water de wijk zal nemen, gebruikt de Indiaan een pijl met een losse punt. Een kleine harpoen wordt aan een dun touw vastgemaakt. Dit touw, soms vijf à zes meters lang, is aan de schacht bevestigd en ligt vóór het afschieten opgerold, om een in de schacht gedreven dunnen stok. Wordt de visch nu geraakt, dan ontrolt zich het touw en fungeert de soms wild ronddrijvende en telkens onderduikende schacht als een boei.

$\mathrm{Nu}$ zullen wij nog het vangen van visch met behulp van vergift, het zoogenaamde ponsen, bespreken. De primitieve bewoners van Suriname, de Indianen, gebruiken vier vischvergiften, 
alle vier planten, waarvan slechts één, de Nekoe, wild in het bosch groeit, terwijl de overige als cultuurgewassen aangemerkt moeten worden. De Nekoe, (Lonchocarpus spec.) een Leguminosae, is een liaan, die in het oerwoud, soms over groote oppervlakten verspreid groeit. In de nabijheid van de Indiaansche en Boschnegervestigingen is deze plant zoo goed als uitgeroeid. Het giftig bestanddeel heeft veel overeenkomst met derrid en is een mengsel van giftige kristallen en harsen, dat echter geen stikstof bevat. Doordat het voornaamste bestanddeel, het nekoeĩd, slechts 1: 100.000 oplosbaar is, levert het water, waarin het opgelost wordt, voor menschen geen gevaar op en er kan ook niet van vergiftigde visschen gesproken worden. Deze laatsten zijn echter zeer gevoelig voor nekoe en naarmate groote of geringe hoeveelheden gebruikt worden, zijn ook de opbrengsten aan visch grooter of kleiner. Het spreekt van zelf, dat hierbij de uitgestrektheden water, die geponst worden, den doorslag geven. In kleine kreken en besloten plassen kan met geringe hoeveelheden nekoe volstaan worden. Hierdoor wordt dan alle visch gedood, en zelfs kreeften en schildpadden, die zich op het droge redden, sterven daarna. Wil men zich in de groote rivieren een goede vangst verzekeren, dan moeten enorme hoeveelheden der liaan gebruikt worden.

Met Kerstmis van 1927 was ik getuige van een ponsoe op zeer groote schaal. Het grootopperhoofd der Saramaccanen, de Bosch negers, die aan de Surinamerivier wonen, was door het Bestuur opgeroepen om voor een vergadering der hoofden, onder leiding van een ambtenaar, naar het dorp Baaikoetoe, gelegen stroomafwaarts van de groote vallenreeks, te komen. Hem zouden talrijke hoofden uit de bovenrivier vergezellen. Na mijn aankomst te Baaikoetoe trok een groot aantal van de bewoners der omliggende dorpen het bosch in, om nekoe te halen. Twee bootladingen dezer liaan werden naar eenige rotsplaten bij den ingang gebracht van de Baaikoetoepratti, een meer dan honderd meters breed kanaal der rivier, dat door haar rechteroever en een meer dan een kilometer lang eiland wordt gevormd. Den geheelen eersten Kerstdag was een groot aantal mannen bezig met de veelal armsdikke stammen in kleine stukken te kappen en daarna met knuppels tot vezels te slaan. Groote hoopen vezels lagen tegen den avond op de rotsplaten opgestapeld. Men had vooral zorg gedragen, dat geen afval in de rivier terecht kwam, waardoor de voorbij trekkende visschen voortijdig gewaarschuwd zouden hebben kunnen worden. De regens waren nog niet in- 
gevallen, daarom was de waterstand in de rivier zeer laag en waren de vooruitzichten op een rijke vangst zeer gunstig.

Des ochtends van den tweeden Kerstdag begaven zich de vrouwen en meisjes naar de rotsplaten, waarop de groote voorraden nekoe bijeengebracht waren en begonnen de vezels in het water uit te wasschen. Intusschen waren door de mannen alle vaartuigen mobiel gemaakt, meer dan vijftig bemande corjalen hadden hun posities op verschillende plaatsen in de pratti en in de stroomversnellingen stroomafwaarts ingenomen. Ook ik had $\mathrm{mij}$ op het water begeven, teneinde dit buitengewone schouwspel gade te kunnen slaan en ook om wat visch te kunnen bemachtigen. Op de rivier heerschte een groote drukte; van heinde en ver kwamen corjalen opdagen om wat kwamba, dat is toespijs bij de rijst en de cassave, op te doen. De toch reeds luidruchtige Boschnegers geraakten opgewonden, toen de eerste groote visschen boven den waterspiegel uit hoog in de lucht sprongen. Tal van kleine vischjes dreven reeds met den buik naar boven voorbij, krabben en kreeften liepen als dronkemannen op de zandbanken en rotsen heen en weer en ook grootere visschen spartelden half bedwelmd in ondiep water. Heen en weer vlogen de corjalen; met pijl en boog schoten de oudere negers op groote visschen, terwijl de jongens met schepnetten den buit binnenhaalden. Tegen den middag was alles afgeloopen; de vangst was buitengewoon groot geweest. Behalve veel sipari, welker giftige zweepstaarten de neger onmiddellijk afhakten, waren ook veel pirins gevangen. De buit was bijzonder groot aan koemaroes, een van de smakelijkste zoetwatervisschen, die het gebied der watervallen nooit verlaten en alleen van vruchten leven. Den volgenden dag was op de rivier niets meer van de ponsoe te bespeuren; de stroom had blijkbaar alle doode visschen weggevoerd.

Een geheel andere ondervinding had ik jaren tevoren in het Savannagebied en wel aan de Surnankreek opgedaan. Toen wij op marsch zijnde, deze kreek naderden, konden wij door den doordringenden stank van rottende visch nauwelijks ademhalen. Indianen hadden eenige dagen tevoren de kreek geponst en een nagenoeg afgesloten moerasgedeelte daarvan was vol doode, reeds sterk in ontbinding verkeerende, visschen.

Vischvangsten met behulp van nekoe op groote schaal, zooals wij hierboven beschreven hebben, worden zelden gehouden. Vooral heeft dit zijn oorzaak in het steeds schaarser worden van de liaan. Voor een eenigszins groote ponsoe moet het noodige vergift op ver afgelegen plaatsen gezocht en vandaar aangevoerd 
worden. Dat kost veel tijd en deze is niet altijd beschikbaar. Vooral echter zijn voor het vervoer een groot aantal dragers noodig; de Boschnegers zijn echter niet spoedig voor onderlinge samenwerking te vinden. Dit komt in het bijzonder uit bij den houtkap, waarbij zij op elkander aangewezen zijn. Men redeneert, dat een enkeling niet meer dan zes à tien houtblokken behoeft te kappen om in zijn behoeften aan kleeren, zout, kruit enz. te voorzien. Met het oog daarop weigert men, wanneer een Boschneger een grooter aantal heeft gekapt, dezen te helpen uitsleepen. Zou een gemeenschap, die buiten het familieverband staat, eischen nekoe te vervoeren, dat slechts aan één dorpsgemeenschap ten goede komt, dan zou men op een besliste weigering stuiten. Ik heb dit in 1917 beleefd. Op meer dan vijftig kilometers west der samenvloeiïng van Gran- en Pikienrio was door een van mijn ploegen, die een lijn naar de Saramacca kapte, een groote hoeveelheid nekoe ontdekt. Na mijn terugkomst aan de rivier deelde ik dit aan het grootopperhoofd mede. Deze had al zijn invloed noodig om een aantal stamleden te bewegen de nekoe te kappen, en eerst nadat men overeengekomen was, dat alles onder een aantal dorpen verdeeld zou worden, toog men aan den arbeid.

De Indianen, die de benedenrivieren bewonen, behelpen zich voor het ponsen der kreken met gewassen, die zij op hun kostgronden verbouwen. Hier komen in de eerste plaats twee eenjarige planten uit de familie der Leguminosae in aanmerking, de Wanapoe en de Koenami, resp. Tephrosia radicaria en Clibadium Surinamense. Van beide planten worden zoowel de stengels en bladeren als ook de wortels gebruikt. De wijze van toepassing is nagenoeg dezelfde als bij nekoe. De gedroogde planten worden fijn gestampt en daarna in het water, waarin men voornemens is te visschen, uitgewasschen, Het gevolg blijft hetzelfde; de visschen raken, vooral in stilstaand water, spoedig bedwelmd, en worden daarna met de hand of met een schepnet gevangen. Verder moeten wij nog een heester, de koenapari (Euphorbia cotinoides), vermelden. Deze plant bevat in al haar deelen een scherp melksap, dat op de huid onmiddellijk blaren geeft en bij spatten in de oogen blindheid veroorzaakt. Men is dan ook uiterst voorzichtig bij het gebruik van Koenapari. De bladeren en twijgjes, die voor het ponsen gebruikt worden, brengt men in een uit den bast van warimbo dicht gevlochten zak en stampt die daarna. Vervolgens wordt de zak met inhoud in het water gelegd, waarna de visschen spoedig aan de oppervlakte komen en sneller sterven dan na gebruik der overige vischvergiften. 
Ik wil ook nog een visscherij van heel bijzonderen aard, waarmede ik aan de Boven Marowijne kennis heb gemaakt, vermelden. De aldaar aan den Franschen oever wonende gouddelvers hebben de vrije beschikking over dynamiet. Zij nemen met deze springstof geladen patronen, steken de lont in brand en werpen ze daarna fluks in het diepe water der rivier. Hoewel men soms in het geheel geen uitwerking waarneemt, is deze dikwijls verbazingwekkend. Na een kortstondige beroering in het water komen visschen in grooten getale en in alle grootten met den buik naar boven aan de oppervlakte en drijven dood met den stroom mede.

Het behoeft geen betoog, dat de hierboven beschreven wijze van visschen, waarbij de jonge visschen door vergift allen om het leven komen en vermoedelijk ook de kuit geheel en al vernietigd wordt, den vischstand in de door de inboorlingen bewoonde streken van het binnenland aantast. Dit merkt men onmiddellijk op, wanneer men dieper het binnenland intrekt en hier een vischrijkdom te aanschouwen krijgt, die aan het ongeloofelijke grenst. Zoo bereikte ik eens de Grankreek, een zijrivier van de Marowijne in haar bovenloop en zag, dat bij den lagen waterstand in de smalle geul honderden anjoemaras, blijkbaar naar lucht happend, aan de oppervlakte kwamen. Ook in de Kabalebo, een zijrivier der Corantijn, aanschouwde ik eens een dergelijke opeenhooping van visch gedurende den drogen tijd. In het verslag van de Suriname-expeditie van 1910 wordt vermeld, dat de arbeiders met verbandwatten als aas aan den hengel, honderden anjoemara uit de Lucierivier opgehaald hebben.

En nu nog eenige mededeelingen omtrent een eigenaardigen visch waarvan wel de meeste lezers eens iets gehoord hebben. Het betreft den sidderaal (Gymnotus electricus L.). Deze merkwaardige visch, die overal in zoetwater voorkomt, waar geen sterke stroom loopt, kan tot andere halven meter lang worden. Hiervan neemt de staart, die voortdurend, ook wanneer de visch stil ligt, in beweging is, wel drie kwart in beslag. Met dezen staart, waarlangs van onderen een vin loopt kan de aal een zeer geduchten slag toebrengen. De eerste slag is altijd de hevigste; alle verdere slagen verliezen in kracht. De Indianen weten dit, daarom laten zij een sidderaal, wanneer zij dezen bemerkt hebben, zijn slagen tegen een stok uitvoeren en nemen den visch tenslotte met de hand uit het water. Bij het visschen in een groote holte, waarin zich de warappen gedurende den drogen tijd terug getrokken hadden, wilde ik met het kapmes de diepte van het schijnbaar 
ondiepe water peilen. Mijn voornemen echter kwam niet tot uitvoer, want een vreeselijke slag deed mij voorover tuimelen, en wanneer een der aanwezige Indianen mij niet gegrepen had, zou ik in het vischgat gevallen zijn. Mijn geheele rechterzijde was als verlamd en een doffe pijn hield wel twee dagen aan. Den rechterarm kon ik den geheelen dag niet meer gebruiken en eerst gedurende den nacht verdween het eigenaardige gevoel en de stijfheid. Een groote sidderaal had tegen het kapmes, dat uit mijn hand werd gerukt, met volle kracht geslagen en mijn arm had de volle lading opgevangen.

Indianen vertelden mij, dat zij door den amansi, zooals de sidderaal in het Caraïbisch genoemd wordt, bijna het leven verloren hadden. De sidderalen hadden hen bij het zwemmen geraakt, waardoor beide beenen verlamden. Slechts doordat zij in de gelegenheid waren zich aan boomwortels vast te klampen, konden zij het leven er af brengen.

De Indianen roosteren den praké of sidderaal en hij wordt gaarne gegeten. De overige, niet electrische alen in Suriname, snekifisi, d.i. slangenvisch, genoemd, zijn treef, dat wil zeggen onrein; de inboorlingen eten geen paling. 